\title{
Sowing Season and Nitrogen Fertilization Rates in Two Oats Cultivars Grown Under Greenhouse Conditions
}

\author{
Luis Aurelio Sanches ${ }^{1}$, Leandro Coelho de Araujo ${ }^{1}$, Sabrina Novaes dos Santos-Araujo ${ }^{1}$, \\ Aline Tais de Carvalho de Oliveira ${ }^{1}$, Antonio Clementino dos Santos $^{2} \&$ Leonardo Bernardes Taverny de Oliveira ${ }^{2}$ \\ ${ }^{1}$ Universidade Estadual Paulista Júlio de Mesquita Filho, Campus de Ilha Solteira, Ilha Solteira, Brazil \\ ${ }^{2}$ Universidade Federal do Tocantins, Campus de Araguaína, Araguaína, Brazil \\ Correspondence: Antonio Clementino dos Santos, Universidade Federal do Tocantins, Campus de Araguaína, \\ Araguaína, Brazil. E-mail: clementino@uft.edu.br
}

Received: May 16, 2018

doi:10.5539/jas.v10n9p133
Accepted: June 16, 2018 Online Published: August 15, 2018

URL: https://doi.org/10.5539/jas.v10n9p133

\begin{abstract}
Two experiments were carried out in the experimental field of the Universidade Estadual Paulista-UNESP in Ilha Solteira, São Paulo state, Brazil, in a greenhouse from April to July 2015. This study aimed at evaluating the best sowing season and response to nitrogen doses for the cultivars of yellow oat São Carlos and black IAPAR 61. The experiments were conducted in randomized blocks designs in a factorial scheme with three replicates. The sowing seasons were April 23, May 08, and May 5 and the nitrogen doses were $0 ; 12.5 ; 25 ; 35.5$ and $50 \mathrm{~kg} \mathrm{ha}^{-1}$ cycle. Harvests at 30 and 60 days were conducted in order to estimate of the production of dry weight (DW), crude protein (CP), neutral detergent fiber (NDF) and acid detergent fiber (ADF). For a productivity of DW, there was interaction between sowing season and oat cultivars and significant differences for $\mathrm{CP}$ in the second harvesting. For NDF, a significant difference was observed between harvesting. The most suitable time for sowing of both yellow oats and black oats is early May. Dry weight yield and the CP content of yellow oats increased linearly with increasing nitrogen rates while for black oats a maximum DM yield were obtained with the application of $43.5 \mathrm{~kg} \mathrm{ha}^{-1}$ of $\mathrm{N}$.
\end{abstract}

Keywords: Avena byzantina, Avena strigosa, dry matter, overseeding, seasonality

\section{Introduction}

Overseeding is a widely used technique in southern Brazil and consists of planting a second crop on perennial forage during the winter in order to reduce seasonality and increase the biomass production for grazing. Among the used forage crops, oats are widely applied due to their high nutritive value, good acceptability for cattle and high potential for use in winter, which increases the interest of producers in several regions of Brazil (Rocha et al., 2007). The main species of oats cultivated in Brazil are Avena sativa (L.) and Avena byzantina (C. Koch), both indicated for the production of forage and grains. Avena strigosa (Schreb), which has no value for human consumption, can also be cultivated for animal feeding in the form of pasture, hay (Mori; Fontaneli; Santos, 2012) and silage.

Although oats are known as forages of temperate climates, its cultivation tends to expand to other regions of the Cerrado due to its high capacity of adaptation and production in several types of soils and regions with warmer winter. For example, oat cultivation has been observed throughout the Central South region of the states of São Paulo and Mato Grosso do Sul (CBPA, 2006; Moreira \& Reis, 2007).

In the Southeast region, oats have been cultivated intercalated with other forage species with lower nutritional potential, serving as a bulk for energy and protein for feeding dairy cattle and sheep during the winter season. This action supplies, in parts, the reduction in dry weight (DW) due to seasonality (Oliveira et al., 2005). For regions such as the Northwest of São Paulo and South of Mato Grosso do Sul, studies indicate that irrigation during the winter is not a viable strategy to reduce the oscillation of forage DW production during the year, even when associated with high nitrogen fertilization (Sousa et al., 2005). These authors evaluated the productivity of five cultivars of Panicum maximum irrigated and fertilized with nitrogen levels over a year and found that even with water and nitrogen supply the productivity from April to September was $11,000 \mathrm{~kg} \mathrm{ha}^{-1} \mathrm{of} \mathrm{DM}$, which is lower than the $30,400 \mathrm{~kg} \mathrm{ha}^{-1}$ of DW produced during Spring/Summer. 
In this way, oat overseeding over tropical pastures, such as the Cerrado, has been a viable alternative to raise DW production in the Fall/Winter in warm and mild climate during the winter, which limits the growth of tropical forage grasses. In addition, oats are advantageous because their botanical canopy composition is altered by the increase of the leaf ratio (Olivo et al., 2010; Neres et al., 2011; Silva et al., 2012), resulting in higher nutritional value (Castagnara et al., 2012).

The evaluation of productivity according to sowing season and nitrogen fertilization rates is necessary to establish new recommendations for the cultivation of oats. Therefore, the objective of this work was to study the dry matter yield and the nutritional value of oats cultivars (yellow and black) as a function of sowing seasons and nitrogen fertilization rates under greenhouse conditions.

\section{Method}

Two experiments were conducted under the greenhouse at Universidade Estadual Paulista (UNESP) in Ilha Solteira, São Paulo state, Brazil. The region presents an average annual temperature of $25^{\circ} \mathrm{C}$, with minimum and maximum temperatures of 19.4 and $31.2{ }^{\circ} \mathrm{C}$, respectively. The annual rainfall is $1315 \mathrm{~mm}$ and the relative air humidity is $74.2 \%$ (http: //clima.feis.unesp.br).

A dystrophic Red Latosol was collected from 0 to $20 \mathrm{~cm}$, passed through a 4-mm sieve and analyzed for its chemical parameters: $\mathrm{pH}$ in $\mathrm{CaCl}_{2} 4.2$, organic matter $25 \mathrm{~g} \mathrm{dm}^{-3}, 4 \mathrm{mg} \mathrm{dm}^{-3}$ of $\mathrm{P}, 1,4,3$ and 58,66 , and $3 \mathrm{mmol}_{\mathrm{c}}$ $\mathrm{dm}^{-3}$ for $\mathrm{K}, \mathrm{Ca}, \mathrm{Mg}$ and $\mathrm{H}+\mathrm{Al}, \mathrm{CEC}$ and $\mathrm{S}_{-} \mathrm{SO}_{4}$ respectively; 8,12 and $58 \%$ for $\mathrm{SB}, \mathrm{V}$ and $\mathrm{M}$ respectively; and $0.21,1.7,42,22.6$ and $0.4 \mathrm{mg} \mathrm{dm}^{-3}$ of $\mathrm{B}, \mathrm{Cu}, \mathrm{Fe}, \mathrm{Mn}$, and $\mathrm{Zn}$, respectively. Liming was performed to increase saturation by $70 \%$ and fertilization with simple superphosphate and potassium chloride was applied as recommended by the Technical Bulletin for Oats (Raij et al., 1997). The studied cultivars were yellow São Carlos (Avena byzantina C. Koch) e Black IAPAR 61 (Avena strigosa Schreb), which was cultivated under irrigation to maintain soil moisture close to field capacity.

Oats were planted in pots containing $10 \mathrm{~kg}$ of soil. A block design with a factorial scheme and three replications were set for the sowing season, which corresponded to three planting seasons (April 23, May 8 and May 23, 2015) and two oats cultivars (yellow and black). As for the nitrogen fertilization rates, five doses of nitrogen $(\mathrm{N}=0,12.5$, $25,35.5$ and $50 \mathrm{~kg} \mathrm{ha}^{-1}$ cycle $^{-1}$ ) and the two oats cultivars were used.

For the experiment of sowing season, standard nitrogen fertilization as ammonium sulfate $\left(50 \mathrm{~kg}\right.$ of N ha $\left.\mathrm{cycle}^{-1}\right)$ was applied at the beginning of sowing and after the first harvest (Oliveira et al., 2005). For the experiment of nitrogen fertilization rates, the treatments were applied in cover at the beginning of sowing and after the first harvest.

Sowing of black and yellow oats in both experiments was carried out in $1.5 \mathrm{~cm}$ deep pits with a sowing rate equivalent to $100 \mathrm{~kg} \mathrm{ha}^{-1}$ (Oliveira et al., 2005). For the experiment of nitrogen fertilization rates, sowing occurred on May 11, 2015. After sowing, all experimental units were fertilized with $50 \mathrm{~kg} \mathrm{ha}^{-1}$ of $\mathrm{P}_{2} \mathrm{O}_{5}$ and $\mathrm{K}_{2} \mathrm{O}$ using superphosphate and potassium chloride, respectively.

The green mass sampling was performed at 30 and 60 days after germination, simulating the management recommendation for the state of São Paulo (Oliveira et al., 2005). The oat plants were cut at a height of $10 \mathrm{~cm}$ relative to the soil and the growth of the subsequent cycle. After cutting, the green mass was weighed and the DW was determined after oven drying at $60^{\circ} \mathrm{C}$ to constant weight. After drying the material was milled in a $1 \mathrm{~mm}$ knife mill for analysis of crude protein (CP), neutral (NDF) and acid (FDA) detergent fibers according to Silva and Queiroz (2009).

\subsection{Statistical Analysis}

Statistical analyzes were performed using the SAS (2002) software, version 9.0. For the experiment of sowing seasons, analyzes of variance were performed by the mixed model procedure considering the complete randomized block design with a factorial scheme and three replications. The means were adjusted by the least squares method and compared to the significance level of 5\% of probability by the Tukey test. Regarding the response to nitrogen doses, regression analysis by the PROC REG procedure were used and the equations with significance of $5 \%$ probability were considered significant.

\section{Results}

\subsection{Sowing Seasons}

The statistical analysis for the production of total dry matter showed interaction effects between sowing seasons and oat cultivars for the first $(p=0.0002)$ and second harvesting $(p=0.004)$. Table 1 shows the total dry weight of the oats cultivars and sowing season for two harvests in consecutive growth cycles. 
Table 1. Productivity of total dry weight of the oats and sowing season for two harvests in consecutive growth cycles

\begin{tabular}{lll}
\hline \multirow{2}{*}{ Sowing } & \multicolumn{2}{c}{ Oats } \\
\cline { 2 - 3 } & Yellow & Black \\
\hline First harvest $\left(\mathrm{kg} \mathrm{ha}^{-1}\right)$ & $847 \mathrm{Ab}$ & $868 \mathrm{Aa}$ \\
2 & $1209 \mathrm{Aa}$ & $884 \mathrm{Ba}$ \\
3 & $644 \mathrm{Bc}$ & $839 \mathrm{Aa}$ \\
\hline Second harvest $(\mathrm{kg} \mathrm{ha}$ & & \\
1 & $2849 \mathrm{Ab}$ & $2994 \mathrm{Aab}$ \\
2 & $8469 \mathrm{Aa}$ & $4814 \mathrm{Ba}$ \\
3 & $644 \mathrm{Ab}$ & $839 \mathrm{Ab}$ \\
\hline
\end{tabular}

Note. Sowing $1=$ April 23, Sowing $2=$ May 8, and Sowing 3 = May 23; First harvest = May 28 and Second harvest June $27,1=$ June 12 and $2=$ July 12 and $1=$ June 27 and $2=$ July 27 . The same uppercase letters in the row and the lower case letters in the column do not differ from each other by the Tukey test at 5\% probability for the same harvest. The standard error of the mean is shown in parentheses.

Significant differences were observed between the oats for the second and third sowing seasons in the first harvest and in the second sowing of the second harvest. The average yield of DW in the first harvest for black oats was similar, regardless of the sowing season, with an average value of $868 \mathrm{~kg} \mathrm{ha}^{-1}$. As for yellow oats, the highest productivity was observed for the second sowing, with a value of $1209 \mathrm{~kg} \mathrm{ha}^{-1}$ (Table 1).

The result of production of total dry weight for black oats in the second harvest first sowing was $2994 \mathrm{~kg} \mathrm{ha}^{-1}$, which is similar to the production observed by Ferolla et al. (2007) (2686.28 kg ha ${ }^{-1}$ ) in their studies of total dry matter production, forage mass composition and leaf/stem ratio of black and triticale oats (Triticosecale Wittmack), with harvesting being carried out in June 2015.

The value of $1209 \mathrm{~kg} \mathrm{ha}^{-1}$ for yellow oats in the first sowing of the first harvest is similar to the data obtained by Martinez and Costa (1987), who found $1500 \mathrm{~kg} \mathrm{ha}^{-1}$ in the second harvest, 24 days after the first harvest. The first harvest was done 46 days after sowing with a third harvest, 22 days after sowing. The same authors obtained a total dry matter production of $5490 \mathrm{~kg} \mathrm{ha}^{-1}$ in these three harvests in a cycle of 92 days. This result is inferior to that reached in the study (up to $8500 \mathrm{~kg} \mathrm{ha}^{-1}$ ), considering only one harvest for yellow oats observed in the second sowing season.

For non-irrigated conditions, in Paraná State, Sanches et al. (2015) observed an average dry weight production of $1512 \mathrm{~kg} \mathrm{ha}^{-1}$, using a basic fertilization of $50 \mathrm{~kg} \mathrm{~N} \mathrm{ha}^{-1}$ cycle ${ }^{-1}$ with a total of five cycles. This result is similar to that adopted in the present study. The authors reported that when oats were irrigated this yield increased to $2760 \mathrm{~kg}$ $\mathrm{ha}^{-1}$. In the present study, the maximum values observed were 8469 and $4814 \mathrm{~kg} \mathrm{ha}^{-1}$ for yellow and black oats, respectively, in the second harvest of the second sowing season, showing the productive potential of oats in the studied climatic conditions (Table 1).

Considering the results of the second harvest of the first sowing season, black oats $2994 \mathrm{~kg} \mathrm{ha}^{-1}$ and yellow oats $2849 \mathrm{~kg} \mathrm{ha}^{-1}$, similar production was found by Cecato et al. (1998), in the region Maringá, Parana State. In their study, which focused on evaluating oat cultivars and strains, they found yields of dry weight production of 2385 to $3136 \mathrm{~kg} \mathrm{ha}^{-1}$, respectively. Generally, there is an increase in the production of oats during the first grazing, resulting in an increase in the number of tillers. Thus, higher yields in the second harvest are expected.

There were no differences $(\mathrm{p}>0.05)$ for CP in the first harvest, which presented an average value of $24.1 \%$. For the second harvest, only the effect of sowing season $(\mathrm{p}=0.0051)$ was observed, with the first two sowing seasons being similar to each other (12.2 and 13.7\%, respectively), which was different from the third $(9.60 \%)$.

Moreira et al. (2005), when evaluating different oat genotypes for forage production and chemical composition, in the Jaboticabal region, São Paulo State, obtained CP values for black oats of 18.6 and 13.1\% for the first and second harvest respectively. This result is similar to that observed in the present study, which presented $12.66 \%$ of $\mathrm{CP}$ for the second harvest of the first sowing season and $13.98 \%$ of CP for the second harvest of the second sowing season.

In evaluations of different cultivars and strains of oats, Godoy and Batista (1990) verified that during the second harvest, 140 days after sowing, the $\mathrm{CP}$ contents varied from 10 to $13 \%$. The low values were justified due to the age 
of the plant and the harvesting season, which caused a decrease in the quality of the forages. These results are very similar to the present study for both oat cultivars.

The CP values observed in this experiment for the first harvest are close to those observed by Cecato et al. (2001), who studied 18 strains of oats and found variation in CP values from 17.1 to $22.3 \%$. For the second harvest, the values were much lower probably because 30 days of growth was considered fixed for the harvests.

Although this period is an indication of intervals between grazing for overseeding in pastures in the Southeast region (Oliveira et al., 2005), it was observed that at the time of the second harvest, a significant part of the plants had inflorescence, suggesting that growth periods of less than 30 days ought to be studied.

For NDF, effects of sowing season $(p=0.0001)$ and oat cultivars $(p=0.005)$ were observed for the first harvest, while for the second harvest only effects of oat cultivars were observed $(p=0.0094)$ (Table 2). The highest NDF content was observed for black oats in the first harvest (up to 16.6\%) (Table 2). Regarding sowing season, the lowest NDF content was observed for the last sowing season, which is related to the lower development and productivity at that time (Table 2), which cause less fibrous tissue production.

Table 2. Percentage of NDF of oat cultivars and sowing season for both harvests in consecutive growth cycles

\begin{tabular}{llll}
\hline \multirow{2}{*}{ Sowing season } & \multicolumn{2}{c}{ Oats } \\
\cline { 2 - 4 } & Yellow & Black & Mean \\
\hline First harvest (\%) & 36.6 & 40.1 & $38.3 \mathrm{~A}$ \\
2 & 37.8 & 48.6 & $43.2 \mathrm{~A}$ \\
3 & 27.6 & 30.2 & $28.9 \mathrm{~B}$ \\
Average & $34.0(1.1) \mathrm{B}$ & $39.6(1.0) \mathrm{A}$ & \\
- Second harvest (\%) & & & \\
1 & 50.7 & 62.3 & 53.5 \\
2 & 51.6 & 58.6 & 53.8 \\
3 & 50.3 & 59.7 & \\
Average & $50.1 \mathrm{~B}$ & $58.2 \mathrm{~A}$ & 55.1 \\
\hline
\end{tabular}

Note. Sowing 1 = April 23, Sowing $2=$ May 8, and Sowing $3=$ May 23. Same letters do not differ by Tukey test at $5 \%$ probability. The standard error of the mean is shown in parentheses.

Mean values of $50.1 \%$ NDF were obtained in this study for yellow oats, which are close to those obtained by Moreira et al. (2007), in the third grazing with $49.7 \%$ of NDF also with yellow oats. In the present study, it was observed a value of $48.6 \% \mathrm{NDF}$ for black oats from the second sowing season of the first harvest, which is similar to the results found for NDF for the first $45.1 \%$ and second $49.7 \%$ grazing from the same authors.

Levels of NDF are similar to those observed by Cecato et al. (2001) in 18 lineages of oats. The authors observed a maximum value of $40.6 \%$, compared to $58.2 \%$ of this study. Despite the differences between oat NDF contents, it is important to point out that these values are considered low when compared to those observed in tropical grasses.

There were no differences ( $p>0.05$ ) for ADF in the first and second harvests, which presented mean values of 19.3 and $30.9 \%$, respectively.

\subsection{Nitrogen Fertilization Rates}

In the first harvest, no significant adjustments of the parameters $(\mathrm{p}>0.05)$ were observed for total dry weight, $\mathrm{CP}$, NDF and ADF for black oats, which presented mean values of 639.4, 25.6, $41.3 \mathrm{~kg} \mathrm{ha}^{-1}$, and 27.6\%, respectively. In the case of yellow oats, significance was observed for all evaluated variables as shown in Figure 1A, 1B and 1C. 

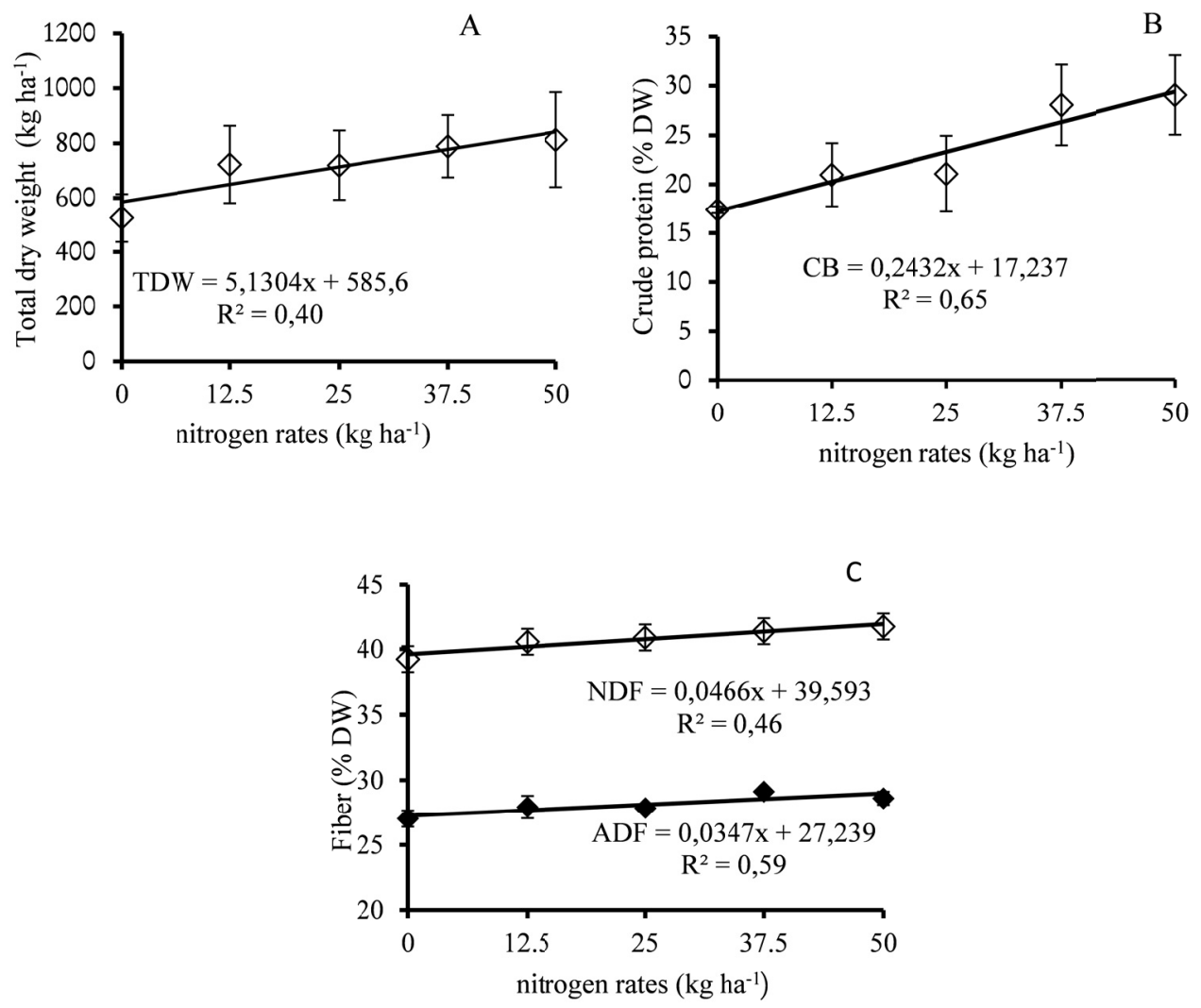

Figure 1. (A) Total dry weight (TDW); (B) Increase of crude protein (CP); (C) Neutral detergent fiber (NDF) and acid detergent fiber (ADF) content for yellow oats according to the nitrogen rates for the first harvest. The vertical bars represent the standard deviation of the mean

For the total dry weight, the best adjustment of the parameters was linear, indicating that yellow oats present conditions to respond to doses greater than $50 \mathrm{~kg}$ of $\mathrm{N} \mathrm{ha}^{-1} \mathrm{cycle}^{-1}$. Within the doses used, an average accumulation of $5.1 \mathrm{~kg}$ per $\mathrm{kg}$ of $\mathrm{N}$ applied was observed, according to the angular coefficient of the equation (Figure 1A).

For CP, a positive linear increase was observed according to increases in nitrogen doses (Figure 1B). The angular coefficient indicated an increase of $0.24 \%$ of $\mathrm{CP}$ for each $\mathrm{kg}$ of $\mathrm{N}$ applied and that $65 \%$ of this variation can be justified by the variation of the doses, as observed by $\mathrm{R}^{2}$, indicating that the adjusted equation can be used as a parameter to estimate total dry weight under the conditions studied.

Considering that the parameters were linearly adjusted, it is not possible to infer the dose that gives the highest $\mathrm{CP}$ concentration in yellow oats. However, the results suggest the hypothesis that doses greater than $50 \mathrm{~kg}^{\circ} \mathrm{N} \mathrm{ha}^{-1}$ cycle $^{-1}$ could be evaluated in future studies as previously discussed.

The statistical analyzes for NDF and ADF in yellow oats are presented in Figure 1C. For these variables, the best fit of the parameters was linear with an average increase of 0.046 and $0.03 \%$ in NDF and ADF, respectively, for each $\mathrm{kg}$ of $\mathrm{N}$ applied. The mean increase in NDF is close to the values found by Cecato et al. (2001). Despite the positive increases, these values are low since the maximum estimated values were 41.9 and $28.9 \%$ for NDF and ADF, respectively (Figure 1C). Thus, the studied nitrogen doses did not contribute to nutritional negative effects.

In the second harvest, no significant differences $(p>0.05)$ were observed for ADF for yellow oats, which presented a mean value of $31.8 \%$. For black oats, no significant differences $(p>0.05)$ were observed for CP and $\mathrm{ADF}$, which presented mean values of 12.1 and $33.5 \%$, respectively.

For black oats, the best fit for NDF was quadratic, indicating an increase in fiber content followed by a peak, with a subsequent decrease (Figure 2). Using the calculation of the maximum point of the equation, the nitrogen dose for the highest NDF concentration corresponding to $24.75 \mathrm{~kg} \mathrm{ha}^{-1}$ with $60 \%$ NDF was estimated. 


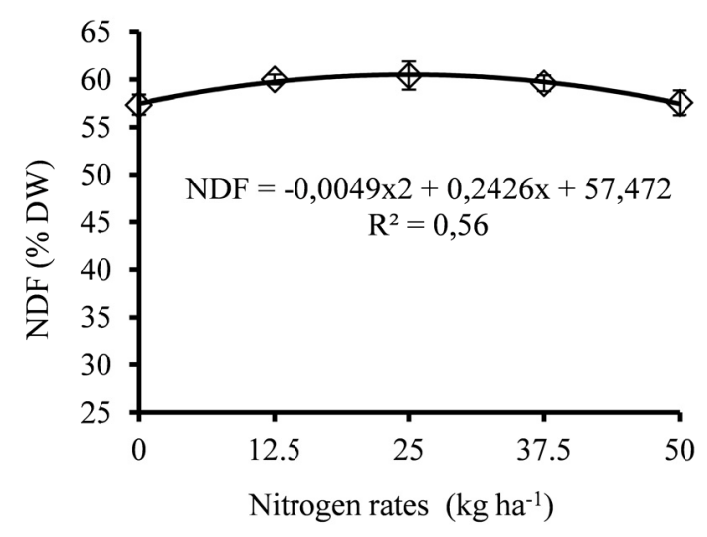

Figure 2. Neutral detergent fiber content (NDF) in black oats, according to the nitrogen rates for the second harvest. Vertical bars represent the standard deviation of the mean

The yellow oat fiber contents adjusted to the quadratic curve, indicating that there was a dose for the largest increment of this variable (Figure 3).

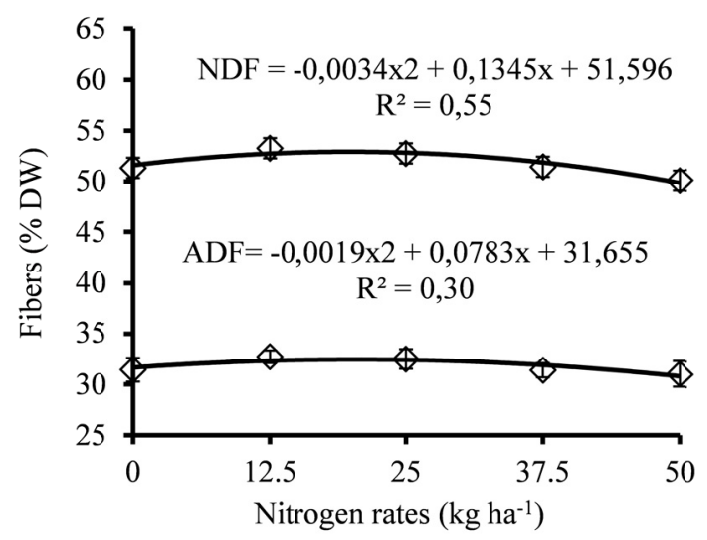

Figure 3. Variation in the content of neutral (NDF) and acid (FDA) detergent fibers in yellow oats, according to the nitrogen rates for the second harvest. Vertical bars represent the standard deviation of the mean

The highest NDF increment dose was $19.8 \mathrm{~kg} \mathrm{ha}^{-1} \mathrm{~N}$, with fiber content of $52.9 \%$ at that dose.

For $\mathrm{CP}$ and total dry weight, the best fit continued to be linear, which means that the maximum incorporation dose of CP and PMS is not in the dose range analyzed in the experiment (Figures 4 and 5). However, the highest CP concentration was $15.8 \%$, which is close to the average of $16.7 \%$ observed for five growth cycles by Sanches et al. (2015), when studying oats as an overgrazing option in Tifiton- 85 pasture in Paraná using basic fertilization of 50 $\mathrm{kg} \mathrm{N} \mathrm{ha}{ }^{-1} \mathrm{cycle}^{-1}$. 


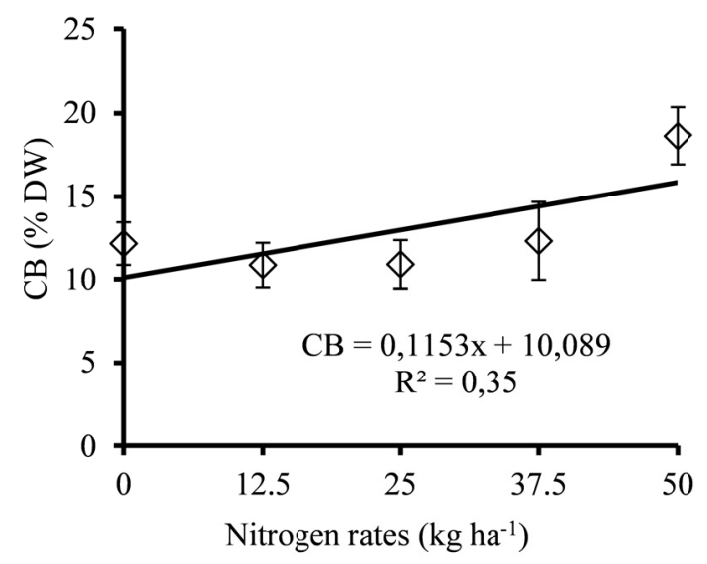

Figure 4. Variation in crude protein content (PB) in yellow oats, according to nitrogen rates for the second harvest. Vertical bars represent the standard deviation of the mean

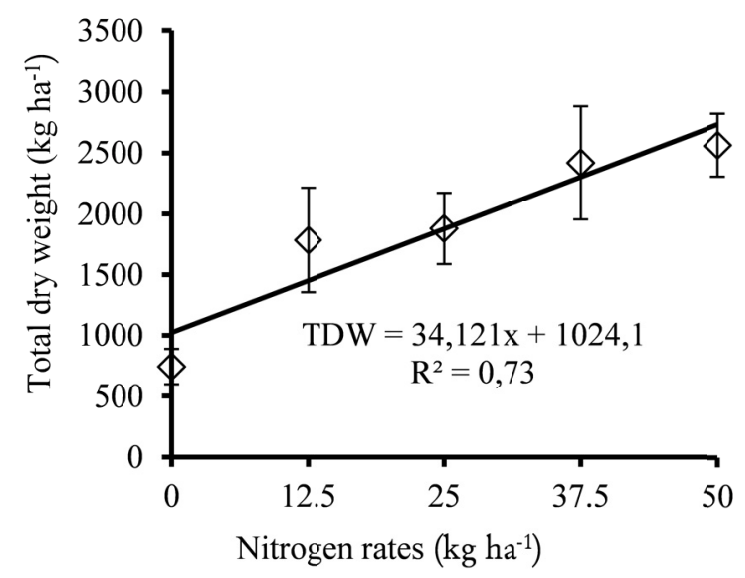

Figure 5. Total dry weight (TDW) of yellow oats, according to nitrogen rates for the second harvest. Vertical bars represent the standard deviation of the mean

The accumulation of DM for black oats followed a different behavior from that observed for yellow oats (Figure 6). For black oats, the quadratic parameter adjustment was significant $(\mathrm{p}<0.05)$ and the maximum total observed was $2681 \mathrm{~kg} \mathrm{ha}^{-1}$ for the dose of $43.5 \mathrm{~kg} \mathrm{ha}^{-1}$ of N (Figure 5). 


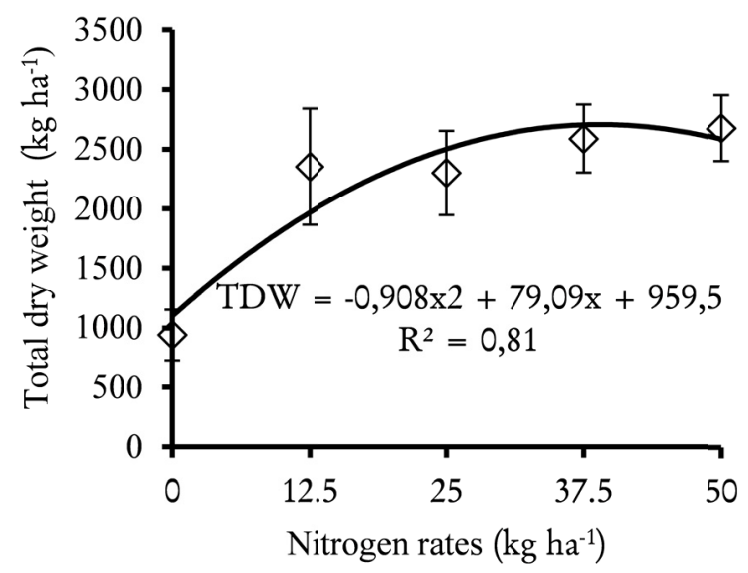

Figure 6. Variation in total dry weight of black oats according to nitrogen rates for the second harvest. Vertical bars represent the standard deviation of the mean

For non-irrigated conditions in Paraná, Sanches et al. (2015) observed average total dry weight of $1512 \mathrm{~kg} \mathrm{ha}^{-1}$, using basic fertilization of $50 \mathrm{~kg} \mathrm{~N} \mathrm{ha}^{-1} \mathrm{cycle}^{-1}$, for five cycles. The authors reported that when oats were irrigated this value increased to $2760 \mathrm{~kg} \mathrm{ha}^{-1}$.

\section{Conclusions}

The first decennial of May is the ideal time for the sowing of the studied oats and the dry weight productivity tends to increase in the subsequent harvest.

Yellow oats present higher productivity when compared to black oats. Yellow oats respond linearly to dry weight production and crude protein concentration with increasing nitrogen rates, while black oats presented the maximum dry weight yield at the dose of $43.5 \mathrm{~kg}$ of $\mathrm{N}$.

\section{Acknowledgments}

To the Foundation for Research Support of the State of São Paulo (FAPESP), process 2014/10201-6.

\section{References}

Castagnara, D. D., Neres, M. A., Oliveira, P. S. R., Jobim, C. C., Três, T. T., Mesquita, E. E., \& Zambom, M. A. (2012). Use of a conditioning unit at the haymaking of Tifton 85 overseeded with Avena sativa or Lolium multiflorum. Revista Brasileira de Zootecnia, 41(6), 1353-1359. https://doi.org/10.1590/S1516-359820120 00600006

CBPA (Comissão Brasileira de Pesquisa de Aveia). (2006). Indicações técnicas para cultura de aveia (p. 82). Guarapurava: Fundação Agrária de Pesquisa Agropecuária.

Cecato, U., Sarti, L. L., Sakaguti, E. S., Damasceno, J. C., Rezende, R., \& Santos, G. T. (2001). Produção e composição química em cultivares e linhagens de aveia (Avena spp.). Acta Scientiarum, 23(4), 775-780. https://doi.org/10.4025/actascianimsci.v23i0.2578

Cecato, U., Sarti, L. L., Sakaguti, E. S., Damasceno, J. C., Rezende, R., \& Santos, G. T. (1998). Avaliação de cultivares e linhagens de aveia (Avena ssp.). Acta Scientiarum, 20(3), 347-354. https://doi.org/10.4025/ actascianimsci.v20i0.4372

Ferolla, S. F., Vásquez, H. M., Silva, J. F. C., Viana, A. P., Domingues, F. N., \& Aguiar, R. S. (2007). Produção de matéria seca, composição da massa de forragem e relação lâmina foliar/caule + bainha de aveia-preta e triticale nos sistemas de corte e de pastejo. Revista Brasileira Zootecnia, 36(5), 1512-1517. https://doi.org/ $10.1590 / \mathrm{S} 1516-35982007000700008$

Godoy, R., \& Batista, L. A. R. (1990) Avaliação de germoplasma de aveia forrageira em São Carlos, SP. Revista da Sociedade Brasileira de Zootecnia, 19(3), 235-241.

Martinez, H. E. P., \& Costa, C. (1988). Rendimento e valor protéico de Avena strigosa cultivada em Selviria, MS. Pesquisa Agropecuária Brasileira, 23(6), 653-657.

Moreira, A. L., \& Reis, R. (2007). A técnica da sobressemeadura de forrageiras de inverno sobre o capimtifton-85. Boletim de Indústria Animal, 64(3), 197-206. https://doi.org/10.1590/S1413-70542007000600035 
Moreira, A. L., Reis, R. A., Ruggieri, A. C., \& Saran Junior, A. J. (2007). Avaliação de forrageiras de inverno irrigadas sob pastejo. Ciências Agrotécnicas, 31(6), 1838-1844.

Moreira, A. L., Simili, F. F., Pedreira, M. S., Gomide, C. A. M., Ruggieri, A. C., \& Silveira, R. N. (2005). Efeito da sobressemeadura de forrageiras de inverno em pasto de capim-Tifton 85 na disponibilidade de massa seca e composição botânica da forragem. Boletim de Indústria, 62(3), 251-264.

Mori, C., Fontaneli, R. S., \& Santos, H. P. (2017). Aspectos econômicos e conjunturais da cultura de aveia (Documentos Online, 136, p. 26). Passo Fundo: Embrapa Trigo. Retrieved March 8, 2017, from http://www.cnpt.embrapa.br/biblio/do/p_do136.htm

Neres, M. A., Castagnara, D. D., Mesquita, E. E., Jobim, C. C., Três, T. T., Oliveira, P. S. R., \& Oliveira, A. A. M. A.. (2011). Production of tifton 85 hay overseeded with white oats or ryegrass. Revista Brasileira de Zootecnia, 40(8), 1638-1644. https://doi.org/10.1590/S1516-35982011000800003

Oliveira, P. P. A. (2007). Recomendação da sobressemeadura de aveia forrageira em pastagens tropicais ou subtropicais irrigadas (Comunicado Técnico, 61, p. 7). São Carlos: EMBRAPA.

Olivo, C. J., Meinerz, G. R., Agnolin, C. A., Steinwandter, E., Ziech, M. F., \& Skonieski, F. R. (2010). Produção de forragem e carga animal de pastagens de Coastcross sobressemeadas com forrageiras de inverno. Revista Brasileira de Zootecnia, 39(1), 68-73. https://doi.org/10.1590/S1516-35982010000100009

Raij, B. Van. (1996). Recomendações de adubação e calagem para o Estado de São Paulo (Boletim Técnico, 100, 2nd ed., p. 285). Campinas: IAC.

Rocha, M. G., Pereira, L. E. T., Scaravelli, L. F. B., Olivo, C. J., Agnolin, C. A., \& Ziech, M. F. (2007). Produção e qualidade de forragem da mistura de aveia e azevém sob dois métodos de estabelecimento. Revista Brasileira de Zootecnia, 36(1), 7-15. https://doi.org/10.1590/S1516-35982007000100002

Sanches, A. C., Gomes, E. P., Rickli, M. E., Fasolin, J. P., Soares, M. R. C., \& Goes, R. H. T. B. (2015). Produtividade e valor nutritivo do capim Tifton 85 irrigado e sobressemeado com aveia. Revista Brasileira de Engenharia Agrícola e Ambiental, 19(2), 126-133, 2015. https://doi.org/10.1590/1807-1929

Silva, C. E. K., Menezes, L. F. G., Ziech, M. F., Kuss, F., Ronsani, R., Biesek, R. R., Boito, B., \& Lisbinski, E. (2012). Overseeded of oat cultivars in grazing African star with different wastes managed forage . Semina: Ciências Agrárias, 33(6), 2441-2450. https://doi.org/10.5433/1679-0359.2012v33n6p2441

Silva, D. J., \& Queiroz, A. C. (2009). Análise de Alimentos-Métodos Químicos e Biológicos (3rd ed., p. 235). Viçosa MG: Editora UFV.

Souza, E. M., Isepon, O. J., Alves, J. B., Bastos, J. F., \& Lima, R. C.(2005). Efeitos da irrigação e adubação nitrogenada sobre a massa de forragem de cultivares de Panicum maximum Jacq. Revista Brasileira de Zootecnia, 34(4), 1146-1155. https://doi.org/10.1590/S1516-35982005000400008

\section{Copyrights}

Copyright for this article is retained by the author (s), with first publication rights granted to the journal.

This is an open-access article distributed under the terms and conditions of the Creative Commons Attribution license (http://creativecommons.org/licenses/by/4.0/). 